\title{
Immunophenotype of Desmoplastic Small Round Cell Tumors as Detected in Cases with EWS-WT1 Gene Fusion Product
}

\author{
Paul J. Zhang, M.D., John R. Goldblum, M.D., Bruce R. Pawel, M.D., Cyril Fisher, M.D.,
}

Teresa L. Pasha, B.S., Frederic G. Barr, M.D., Ph.D.

University of Pennsylvania Medical Center (PJZ, TLP, FGB), Philadelphia, Pennsylvania; Cleveland Clinic Foundation, Cleveland, Ohio (JRG); Children's Hospital of Philadelphia (BRP), Philadelphia,

Pennsylvania; Royal Marsden Hospital, London, United Kingdom (CF)

Desmoplastic small round cell tumor is a rare tumor typically involving peritoneum. Although the histogenesis of desmoplastic small round cell tumor has yet to be elucidated, immunophenotypical and morphological analysis shows a characteristic divergent phenotype overlapping with other round cell tumors such as Ewing's sarcoma/primitive neuroectodermal tumor, rhabdomyosarcoma, small cell mesothelioma, and carcinoma. Detection of the EWS-WT1 gene fusion is characteristic of desmoplastic small round cell tumor and has been used reliably in tumor diagnosis. In this study, we evaluated the immunophenotype of 23 desmoplastic small round cell tumor cases with the $E W S-W T 1$ gene fusion product identified by reverse transcription-polymerase chain reaction. Paraffin sections were stained with antibodies against calretinin, WT1 (C19), desmin, myoglobin, MyoD, Myf5, myogenin, placental alkaline phosphatase, cytokeratins, MIC2, HER2/neu and c-kit using standard immunohistochemical methods. Immunoreactivity was evaluated semiquantitively by light microscopy. Desmoplastic small round cell tumors showed reactivity with calretinin in $4 / 21$, desmin in $21 / 23$, myoglobin in $5 / 17$, placental alkaline phosphatase in 17/21, HER2/neu in $7 / 18$ (3+ in 1 and $1+$ in 6), c-kit in 2/14, MIC2 in 13/23, WT1 in 16/23, CAM5.2 in 21/23, and AE1/3 in 16/23 cases. The most sensitive myogenic and epithelial markers are desmin and CAM 5.2. Although nuclear reactivity of the early myogenic regulatory factors (MyoD, myogenin, My55) was not detected, myoglobin

Copyright ( $(2003$ by The United States and Canadian Academy of Pathology, Inc.

VOL. 16, NO. 3, P. 229, 2003 Printed in the U.S.A

Date of acceptance: December 7, 2002.

Funded in part by National Institutes of Health Grants CA89461 and CA64202 (to FGB).

Address reprint requests to: Paul J. Zhang, M.D., Anatomic Pathology, 6 Founders Pavilion, University of Pennsylvania Medical Center, 3400 Spruce Street, Philadelphia, PA 19147; fax: 215-349-5910; e-mail: pjz@mail.med.upenn.edu.

DOI: 10.1097/01.MP.0000056630.76035.F3 immunoreactivity was present in $29 \%$ of desmoplastic small round cell tumors. HER2/neu overexpression $(3+)$ and c-kit expression are uncommon in desmoplastic small round cell tumors. A panel of myogenic and epithelial markers should be used to detect the divergent phenotype in desmoplastic small round cell tumors, a key feature in the differential diagnosis. Detection of EWS-WT1 fusion becomes critical for the diagnosis when the characteristic divergent phenotype cannot be detected immunohistochemically.

KEY WORDS: Desmoplastic small round cell tumor, EWS-WT1 fusion product, HER2/neu, Immunophenotype.

Mod Pathol 2003;16(3):229-235

Desmoplastic small round cell tumor is a rare but distinct entity with aggressive clinical behavior (1, 2). It was originally described as a tumor primarily involving the abdominal peritoneum, with characteristic small round cell morphology $(1,3-5)$. Although the histogenesis of desmoplastic small round cell tumor has yet to be elucidated, immunophenotypical analysis shows a polyphenotypic differentiation overlapping with other round cell tumors such as Ewing's sarcoma/peripheral neuroectodermal tumors, rhabdomyosarcoma, Wilms' tumor, small cell mesothelioma, and carcinoma (15). Genetic studies revealed a characteristic translocation between the EWS gene on chromosome 22 and the $W T 1$ gene on chromosome 11, resulting in an EWS-WT1 fusion gene (6-8). Detection of EWSWT1 fusion transcript by reverse transcriptionpolymerase chain reaction (RT-PCR) has been used reliably to enhance our ability to diagnose desmoplastic small round cell tumor, particularly for those arising outside the abdominal cavity and those with unusual morphologic variation $(2,7,9)$. Comprehensive immunohistochemical analysis has 
been performed on desmoplastic small round cell tumors in several large series, only few of which had molecular confirmation of the diagnosis in the cases studied (2). In the current study, immunohistochemical evaluation of various markers related to epithelial, myogenic, and mesothelial differentiation was performed on a series of desmoplastic small round cell tumors that showed EWS-WT1 fusion transcript by RT-PCR.

Proto-oncoproteins c-kit (CD117) and HER2/neu are both transmembrane tyrosine kinase receptors that belong to the platelet-derived growth factor receptor (PDGFR) or epidermal growth factor receptor family, respectively $(10,11)$. Expression of c-kit has been detected in some mesenchymal tumors such as gastrointestinal stromal tumors and Ewing's sarcomas/primitive neuroectodermal tumors (12-14). Recently, a tyrosine kinase inhibitor specific for the PDGFR family (STI571) and humanized monoclonal antibody against HER2/neu (Herceptin) have been reported to have therapeutic effects in tumors expressing either aberrant forms or high quantities of the corresponding target protein (15-17). Therefore, STI571 or Herceptin might be effective in treating tumors positive for c-kit or HER2/neu by immunohistochemistry. Little is known about the status of HER2/neu and c-kit immunoreactivity in DSRCT. In this study, we also evaluated the immunoreactivity of HER2 and c-kit in desmoplastic small round cell tumors in the same series of cases with molecular evidence of the EWS/WT1 fusion.

\section{MATERIALS AND METHODS}

Twenty-three desmoplastic small round cell tumors were identified in the consultation file of one of the authors (FGB) and collected from the surgical pathology files of the authors' institutions. The EWS-WT1 gene transcript was previously identified in frozen tissue samples of these cases using a RTPCR method as described elsewhere (18). The immunohistochemical panel consisted of antibodies against the mesothelial markers: calretinin and WT1(WT C-19 against the carboxy terminus of the protein); the myoid/myogenic markers: desmin, myoglobin, MyoD, Myf5 and myogenin; cytokeratins: CAM5.2, AE1/3; proto-oncoproteins: c-kit, HER2/neu and others: placental alkaline phosphatase and MIC2 (CD99; Table 1). Four-micrometerthick paraffin sections were used for standard immunohistochemical methods. Sections were pretreated by heating and enzyme digestion accordingly (Table 1). The heating method involved a $1100-\mathrm{W}$ microwave oven at $70 \%$ power level or a Black \& Decker steamer at $95^{\circ} \mathrm{C}$ with $1 \times$ citrate buffer at $\mathrm{pH} 6.0$ (Lab Vision) or $1 \times$ Target Retrieval Buffer (DAKO, Carpinteria, CA), accordingly (Table 1). Immunohistochemical staining was performed on an autostainer (DAKO) with EnVision kit (DAKO) for all antibodies except MyoD and WT1, for which staining was performed on a Techmate autostainer (Biotech/Ventana, Tucson, AZ) with the avidin-biotin complex method (ChemMate, Biotech/Ventana, Tucson, AZ). Based on the intensity of the immunoreactivity and the percentage of positive tumor cells, immunoreactivity was scored semiquantitively as $\mathrm{F}+$ (any intensity but $\leq 20 \%$ ), $1+$ (weak intensity $>20 \%$ but $\leq 50 \%$ ), $2+$ (weak intensity $>50 \%$, moderate $>20 \%$ but $\leq 75 \%$, or strong $>20 \%$ but $\leq 50 \%$ ), and $3+$ (moderate intensity $>75 \%$ or strong intensity and $>50 \%$ ).

TABLE 1. Antibodies Used in the Study

\begin{tabular}{|c|c|c|c|c|}
\hline Antibody & Clone & Source & Titer & Antigen Retrieval \\
\hline Calretinin & Polyclonal & ZYMED, So. San Francisco, CA & $1: 50$ & $\begin{array}{l}\text { Microwave, } 8 \text { minutes, } 1 \mathrm{X} \text { Citrate } \\
\text { Buffer at pH6.0 }\end{array}$ \\
\hline WT1 (C-19) & Polyclonal & Santa Cruz, Fremont, CA & $1: 400$ & $\begin{array}{l}\text { Microwave, } 8 \text { minutes, } 1 \mathrm{X} \text { Citrate } \\
\text { Buffer at pH6.0 }\end{array}$ \\
\hline Desmin & Polyclonal & DAKO, Carpinteria, CA & $1: 400$ & NA \\
\hline Myoglobin & Polyclonal & DAKO & $1: 40 \mathrm{~K}$ & NA \\
\hline MyoD & $5.8 \mathrm{~A}$ & DAKO & $1: 25$ & $\begin{array}{l}\text { Steamer, } 15 \text { minutes, Target } \\
\text { Retrieval Buffer (DAKO) }\end{array}$ \\
\hline Myogenin & F5D & DAKO & $1: 50$ & $\begin{array}{l}\text { Microwave, } 8 \text { minutes, Target } \\
\text { Retrieval Buffer (DAKO) }\end{array}$ \\
\hline Myf5 (C20) & Polyclonal & Santa Cruz & $1: 50$ & $\begin{array}{l}\text { Microwave, } 8 \text { minutes, Target } \\
\text { Retrieval Buffer (DAKO) }\end{array}$ \\
\hline CAM5.2 & CAM 5.2 & Beck-Dickinson & $1: 25$ & $\begin{array}{l}\text { Microwave, } 8 \text { minutes in } 1 \mathrm{X} \text { Citrate } \\
\text { Buffer at pH6.0 }\end{array}$ \\
\hline $\mathrm{AE} 1 / 3$ & AE1 \& AE 3 & DAKO & $1: 40$ & $0.01 \%$ Trypsin, 15 minutes at $37^{\circ} \mathrm{C}$ \\
\hline PLAP & $8 \mathrm{~A} 9$ & DAKO & $1: 25$ & $\begin{array}{l}\text { Microwave, } 8 \text { minutes, Target } \\
\text { Retrieval Buffer (DAKO) }\end{array}$ \\
\hline MIC 2 & $12 \mathrm{E} 7$ & DAKO & $1: 25$ & $\begin{array}{l}\text { Microwave, } 8 \text { minutes in } 1 \mathrm{X} \text { Citrate } \\
\text { Buffer at pH6.0 }\end{array}$ \\
\hline HER2/neu & TAB250 & ZYMED & $1: 10$ & Ficin (ZYMED), 15 minutes at $37^{\circ} \mathrm{C}$ \\
\hline c-kit & Polyclonal & DAKO & $1: 100$ & $\begin{array}{l}\text { Microwave, } 8 \text { minutes, } 1 \mathrm{X} \text { Citrate } \\
\text { Buffer at pH6.0 }\end{array}$ \\
\hline
\end{tabular}


TABLE 2. Immunohistochemical phenotype of Desmoplastic Small Round Cell Tumors

\begin{tabular}{|c|c|c|c|c|c|c|c|c|c|c|c|c|c|}
\hline & CAM5.2 & $\mathrm{AE} 1 / 3$ & DES & PLAP & MYO & MyoD & MYG & Myf5 & CALR & MIC2 & WT1 & HER2 & c-kit \\
\hline $\mathrm{N}=$ & 23 & 23 & 23 & 21 & 17 & 20 & 22 & 21 & 21 & 23 & 23 & 18 & 14 \\
\hline Neg & 2 & 7 & 2 & 4 & 11 & 20 & 22 & 21 & 15 & 10 & 5 & 11 & 12 \\
\hline $\mathrm{F}+$ & 4 & 4 & 3 & 4 & 1 & 0 & 0 & 0 & 3 & 1 & 2 & 0 & $2^{*}$ \\
\hline $1+$ & 3 & 7 & 6 & 6 & 4 & 0 & 0 & 0 & 1 & 5 & 2 & 4 & 0 \\
\hline $2+$ & 3 & 4 & 7 & 6 & 0 & 0 & 0 & 0 & 0 & 7 & 3 & 2 & 0 \\
\hline $3+$ & 11 & 1 & 5 & 1 & 0 & 0 & 0 & 0 & 0 & 0 & 9 & 1 & 0 \\
\hline Total+ & $\begin{array}{l}21 / 23 \\
(91 \%)\end{array}$ & $\begin{array}{l}16 / 23 \\
(70 \%)\end{array}$ & $\begin{array}{l}21 / 23 \\
(91 \%)\end{array}$ & $\begin{array}{l}17 / 21 \\
(81 \%)\end{array}$ & $\begin{array}{c}5 / 17 \\
(29 \%)\end{array}$ & 0 & 0 & 0 & $\begin{array}{c}4 / 21 \\
(19 \%)\end{array}$ & $\begin{array}{l}13 / 23 \\
(57 \%)\end{array}$ & $\begin{array}{l}16 / 23 \\
(70 \%)\end{array}$ & $\begin{array}{c}7 / 18 \\
(39 \%)\end{array}$ & $\begin{array}{r}2 / 14 \\
(14 \%)\end{array}$ \\
\hline
\end{tabular}

$\mathrm{F} \leq 20 \%$.

$1+$. Weak $>20$ but $\leq 50 \%$.

$2+$. Weak $>50 \%$.

Moderate $>20 \%$ but $\leq 75 \%$.

Strong $>20 \%$ but $\leq 50 \%$.

$3+$ Moderate $>75 \%$.

Strong $>50 \%$.

* Rare cells only.

$\mathrm{DES}=$ desmin $; \mathrm{MYO}=$ myoglobin $; \mathrm{MYG}=$ myogenin $;$ CALR $=$ calretinin; PLAP $=$ placental alkaline phosphatase

\section{RESULTS}

The results of the immunohistochemical analysis on desmoplastic small round cell tumors were summarized on Table 2. In addition to a higher frequency of positivity than that of AE1/3, CAM5.2 immunoreactivity was always stronger $(n=11)$ than or equal $(n=5)$ to that of AE1/3 (Fig. 1). The tumors were only positive for CAM 5.2 in five cases $(22 \%)$ and were negative for both CAM5.2 and AE1/3 in two (10\%). The desmin and placental alkaline phosphatase immunostaining tended to be dotlike or globoid (Fig. 2). Fifteen cases showed immunoreactivity with both desmin and placental alkaline phosphatase, whereas 6 with desmin only and 2 with placental alkaline phosphatase only. Myoglobin immunoreactivity was focal in one and $1+$ in four cases (Fig. 3). In those cases, there was no skeletal muscle tissue present within or near the tumor tissue. No nuclear reactivity was seen with MyoD, Myf5, or myogenin, although weak cytoplasmic reactivity was frequently seen with anti-Myf5 and was considered nonspecific. Only membranous MIC2 immunoreactivity was considered positive, although some MIC2-positive cases also showed weak cytoplasmic immunoreactivity. MIC2 immunoreactivity tended to be focal. HER2/neu membrane immunoreactivity was seen in seven cases, but only one was strong $(3+)$. c-Kit immunoreactivity was seen in rare tumor cells in two cases.

\section{DISCUSSION}

In this study, we evaluated the immunophenotype of desmoplastic small round cell tumors with a panel of antibodies against epithelial, mesothelial, myoid markers, and proto-oncoprotein HER2/neu and c-kit in a series of cases with documented EWS-WT1 fusion product as detected by RT-PCR.

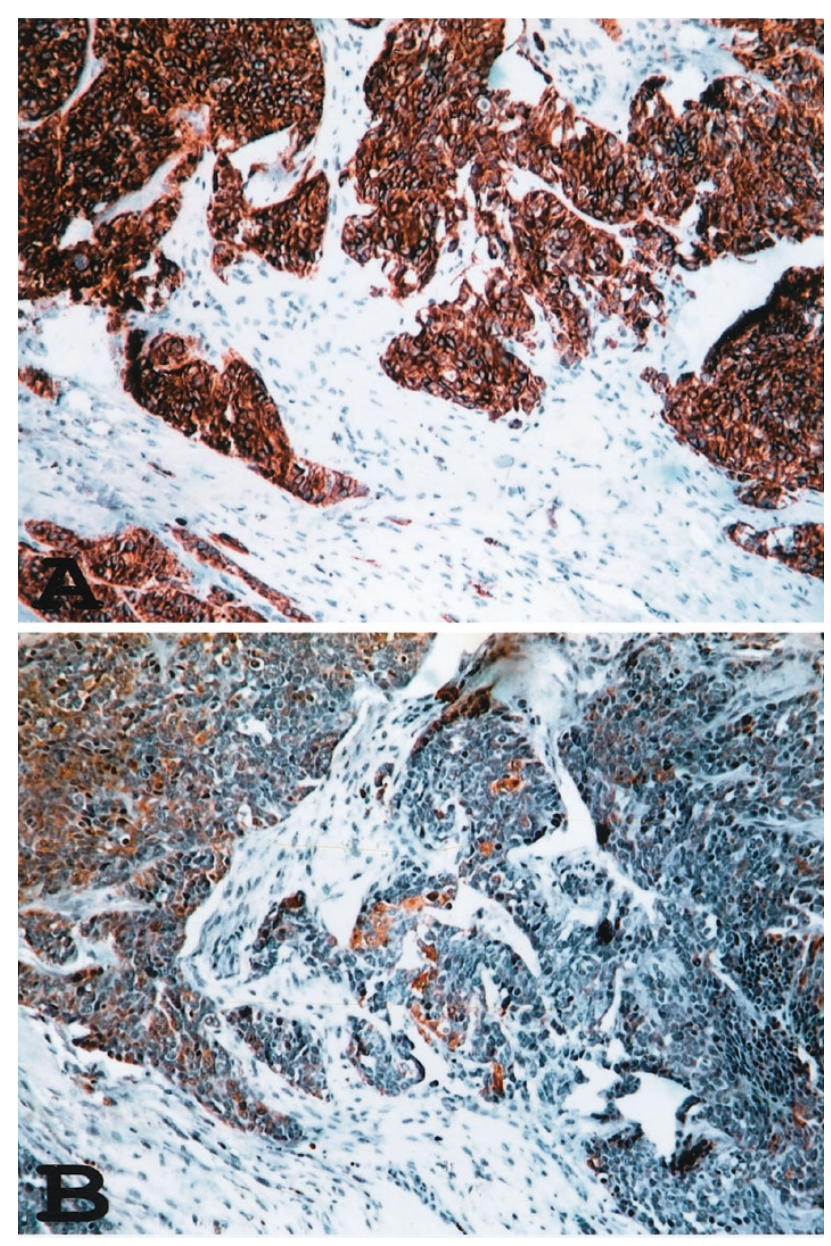

FIGURE 1. Immunoreactivity with anti-CAM5.2 (A) and AE1/3 (B) in a desmoplastic small round cell tumor. (immunoperoxidase staining).

Similar to the findings of previous studies, we found frequent expression of WT1, desmin, and cytokeratin in desmoplastic small round cell tumors $(1,2$, $5,9,19-21)$. In addition, placental alkaline phosphatase immunoreactivity was detected in 17 of 21 (81\%) desmoplastic small round cell tumors. Pla- 


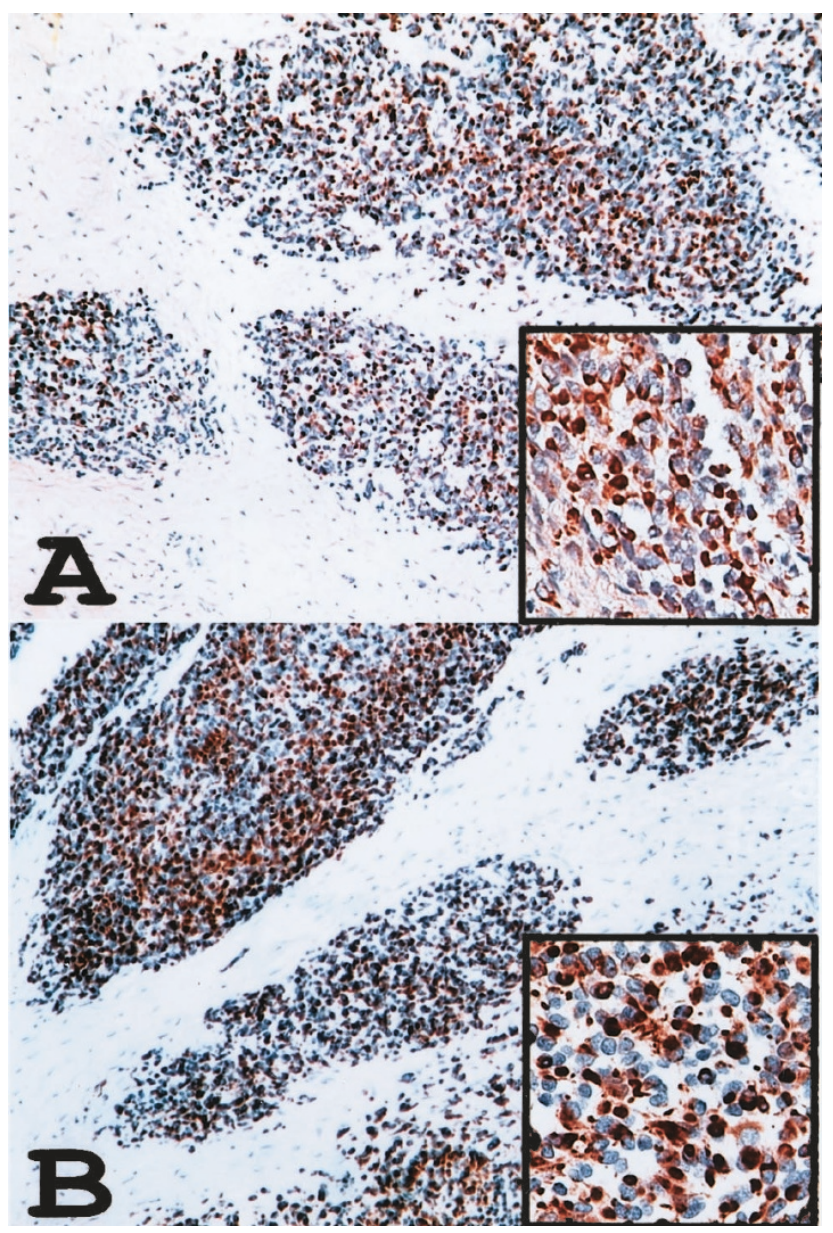

FIGURE 2. Desmin (A) and PLAP (B) immunoreactivity in a desmoplastic small round cell tumor. Note the similar cytoplasmic dot or globoid staining pattern under higher magnification in the inserts (immunoperoxidase staining).

cental alkaline phosphatase is normally expressed as a membrane-bound protein and has been used as a marker for germ cell tumors. Previous studies have reported PLAP negativity in desmoplastic small round cell tumors $(5,21)$. A monoclonal antibody, Clone 886, was used in these studies, and DAKO was indicated as the source of the antibody $(5,21)$. However, there are only two placental alkaline phosphatase monoclonal antibody clones, 8B6 and 8A9, available from DAKO. Likely, Clone 8B6 was misspelled as 886 in the previous articles. The monoclonal antibody (Clone 8A9) used in our study is intended for use on paraffin section, and clone 8B6 has not been indicated for use on paraffin section according to the manufacturer's catalog (DAKO 2002 catalog, p. 113). The difference in detecting placental alkaline phosphatase immunoreactivity in desmoplastic small round cell tumors between the previous studies and ours is likely due to the performance of the different antibodies on paraffin section. We have recently documented frequent placental alkaline phosphatase immunoreac-

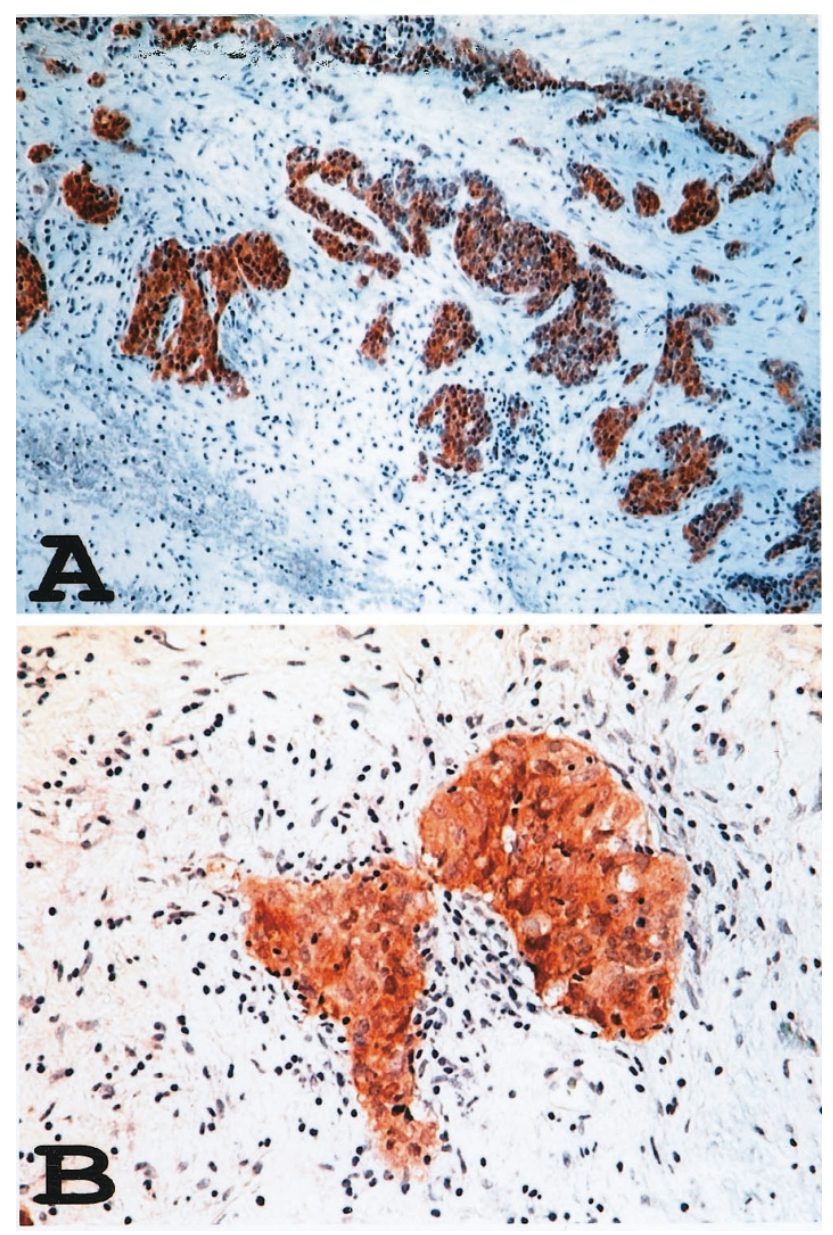

FIGURE 3. Myoglobin immunoreactivity in a desmoplastic small round cell tumor under low (A) and high (B) magnification (immunoperoxidase staining).

tivity in normal muscle tissue and neoplasms with myogenic differentiation (22). Both desmin and placental alkaline phosphatase immunoreactivity tended to be dotlike in the cytoplasm in desmoplastic small round cell tumors. The dotlike desmin staining pattern has been attributed to a characteristic paranuclear inclusions composed of variable intermediate filaments in the tumor cells identified on ultrastructural level $(3,21)$. For the same reason, the dotlike placental alkaline phosphatase immunoreactivity might also be related to this paranuclear collection of intermediate filaments that otherwise have not been well characterized. Placental alkaline phosphatase immunoreactivity in desmoplastic small round cell tumors, therefore, might represent a true aberrant expression in cells with desmin expression or cross-linkage of an unrelated epitope in these filaments, rather than evidence of a germ cell phenotype. Myoglobin immunoreactivity has been used as a marker for skeletal muscle differentiation and reported negative in desmoplastic small round cell tumors in previous series (5, $21)$. In the current study, however, we detected 
focal myoglobin immunoreactivity in 5 (29\%) of 17 desmoplastic small round cell tumor cases by using the same polyclonal antibody used in the previous studies in a significantly more diluted concentration $(1: 1,200$ versus $1: 40,000)$ without antigen retrieval. There is no normal skeletal muscle infiltrated by tumor or adjacent to tumor in these cases; therefore, the focal myoglobin immunoreactivity is unlikely due to perfusion effect sometimes observed in tissue adjacent to injured skeletal muscle. The significance of the myoglobin immunoreactivity in our series is not clear, and a cross-reactivity with other unrelated epitope in these desmoplastic small round cell tumors by the antibody is possible because expression of MyoD, myogenin, and Myf5, all known to play a regulatory role in earlier myogenic differentiation of skeletal muscle, were not identified in any of the cases in previous studies or in ours $(2,5,21)$. More studies are needed to further evaluate the myoglobin immunoreactivity in desmoplastic small round cell tumors.

WT1 expression normally plays a role in mesothelial formation in embryonic development (23). Frequent WT1 expression has been reported in Wilms' tumor and mesothelioma (24). Because of these findings and common involvement of the peritoneum by this tumor, WT1 immunoreactivity in desmoplastic small round cell tumors has raised the possibility that desmoplastic small round cell tumors might be a blastomatous tumor of the mesothelium (24-27). Contrary to this speculation, we found that calretinin, a calcium channel-related protein highly expressed in normal mesothelium as well as mesothelioma $(28,29)$, is negative in the majority of desmoplastic small round cell tumors and only weakly and focally positive in a small fraction of the cases (Fig. 4). These findings support the notion that WT1 immunoreactivity is likely related to expression of a chimeric EWS-WT1 protein product as previously suggested by others $(2,9,19$, 20).

Although MIC2 (CD99), a marker frequently used for the diagnosis of Ewing's sarcomas and primitive neuroectodermal tumors, has been shown to be positive in 20 to $35 \%$ of desmoplastic small round cell tumor cases in previous studies $(2,21)$. We found MIC2 immunoreactivity in up to $57 \%$ of desmoplastic small round cell tumor cases in our study. Given this finding, MIC2 has a limited role in distinguishing desmoplastic small round cell tumors from other MIC2-positive round cell sarcomas, such as Ewing's sarcomas and primitive neuroectodermal tumors.

HER2/neu and c-kit are both proto-oncoproteins involved in cellular growth and differentiation, and alterations of these genes have been implicated in the etiology of certain tumors (10-13).

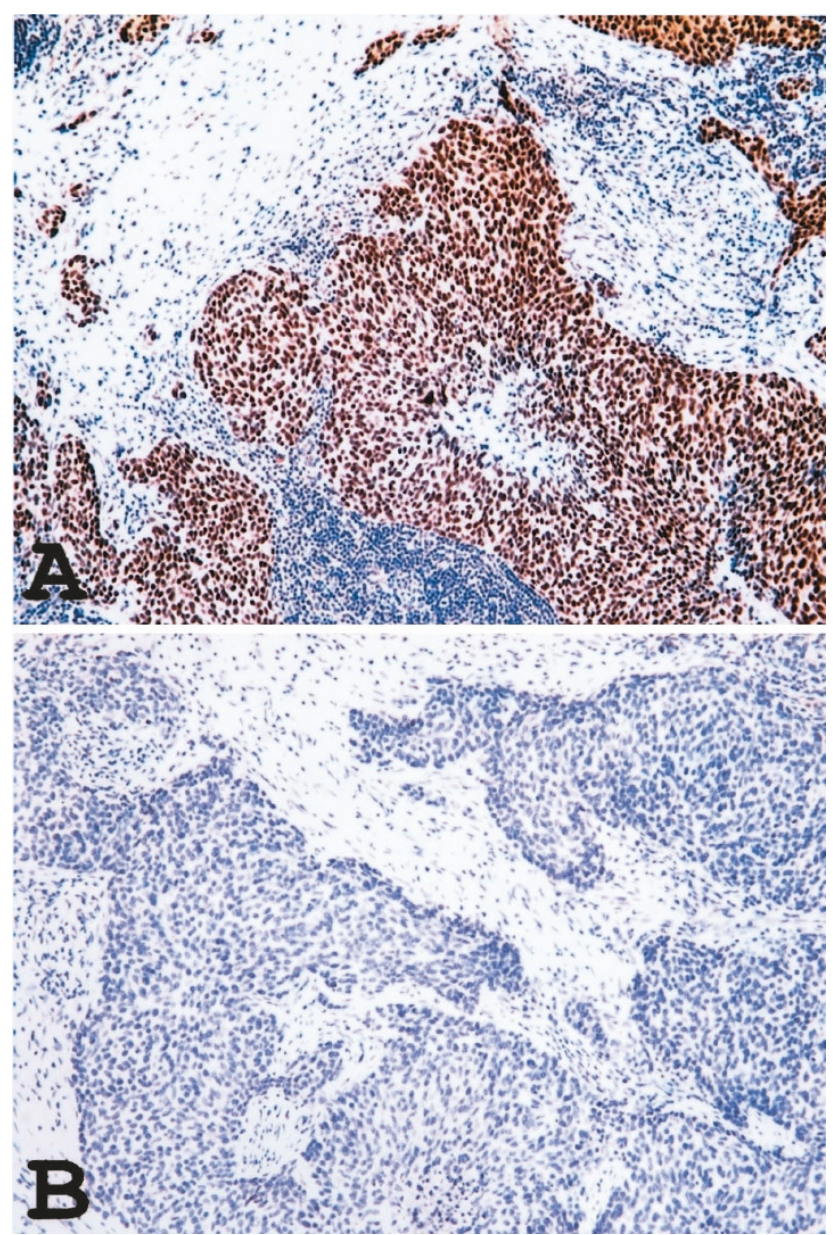

FIGURE 4. Strong nuclear WT1 immunoreactivity (A) and absence of calretinin immunoreactivity (B) in a desmoplastic small round cell tumor (immunoperoxidase staining).

Immunohistochemical analysis of expression of HER2/neu and c-kit in tumor tissue might have therapeutic implication because of recent data demonstrating the effectiveness of a humanized monoclonal antibody against HER2/neu (Herceptin) and a tyrosine kinase inhibitor (STI 571) in treating certain cancers aberrantly expressing the targeted protein (15-17). However, overexpression of HER2/neu and c-kit appeared to be a rare event in desmoplastic small round cell tumors, as only one case $(6 \%)$ showed overexpression of HER $2 /$ neu (as defined by $3+$ and $100 \%$ ), and two cases (14\%) showed rare c-kit immunoreactivity. The lack of c-kit expression in desmoplastic small round cell tumors has also recently been reported in series of 8 cases by Smithey et al. (32). Because of the low frequency of immunodetection, neither HER2/neu nor c-kit seems to have a significant role in tumorigenesis of desmoplastic small round cell tumors, and the use of therapeutic agents targeting these proto-oncoproteins will probably have limited benefit in these tumors. 
The majority of desmoplastic small round cell tumors can be reliably diagnosed based on the characteristic morphology and immunohistochemical profile. Co-expression of myogenic markers and cytokeratin is rarely seen in other round cell tumors and therefore probably is the most specific immunohistochemical profile for the diagnosis of desmoplastic small round cell tumor. A panel of multiple myoid and epithelial markers should always be employed in the immunohistochemical workup of this neoplasm. The most sensitive myoid and epithelial markers are desmin and CAM 5.2 (both 91\%). However, extraabdominal presentation and a wide range of histologic features have been described in desmoplastic small round cell tumors, and the characteristic immunohistochemical profile has not been detected in all desmoplastic small round cell tumors $(2,30,31)$. In such cases, differential diagnosis from other round cell tumors might become difficult, and detection of the EWS-WT1 fusion product by molecular methods would be critical in the diagnosis of desmoplastic small round cell tumor.

\section{REFERENCES}

1. Gerald WL, Miller HK, Battifora H, Miettinen M, Silva E, Rosai J. Intra-abdominal desmoplastic small round-cell tumor. Am J Surg Pathol 1991;15:499-513.

2. Gerald WL, Ladanyi M, de Alava E, Cuatrecasas M, Kushner $\mathrm{BH}, \mathrm{LaQuaglia} \mathrm{MP}$, et al. Clinical, pathologic, and molecular spectrum of tumors associated with $\mathrm{t}(11 ; 22)(\mathrm{P} 13 ; \mathrm{q} 12)$; desmoplastic small round-cell tumor and its variants. J Clin Oncol 1998;16:3028-36.

3. Ordonez NG, Zirkin R, Bloom RE. Malignant small-cell epithelial tumor of the peritoneum coexpressing mesenchymaltype intermediate filaments. Am J Surg Pathol 1989;13:41321.

4. Gonzalez-Crussi F, Crawford SE, Sun C-C. Intraabdominal desmoplastic small-cell tumors with divergent differentiation. Am J Surg Pathol 1990;14:633-42.

5. Ordonez NG, El-Naggar AK, Ro JY, Silva EG, Mackay B. Intra-abdominal desmoplastic small cell tumor: a light microscopic, immunohistochemical, ultrastructural, and flow cytometric study. Hum Pathol 1993;24:850-65.

6. Sawyer JR, Tryka FA, Lewis JM. A novel reciprocal chromosome translocation $\mathrm{t}(11 ; 22)(\mathrm{p} 13 ; \mathrm{q} 12)$ in an intraabdominal desmoplastic small round-cell tumor. Am J Surg Pathol 1992; 16:411-6.

7. De Alava E, Ladanyi M, Rosai J. Detection of chimeric transcripts in desmoplastic small round cell tumor and related developmental tumors by RT-PCR. Am J Pathol 1995;147: 1584-91.

8. Biegel JA, Conrad K, Brooks JJ. Translocation (11:22)(p.13;q12): primary change in intraabdominal desmoplastic small round cell tumor. Genes Chromosomes Cancer 1993;7:119-21.

9. Barnoud R, Dellattre O, Peoch M, Pasquier D, Plantaz D, Leroux D, et al. Desmoplastic small round cell tumor: RTPCR analysis and immunohistochemical detection of the Wilm's tumor gene WT1. Pathol Res Pract 1998;194:693-700.

10. Coussens L, Yang-Feng TL, Chen YLE, et al. Tyrosine kinase receptor with extensive homology to EGF receptor shares chromosomal location with neu oncogene. Science 1985; 230:1132-9.

11. Yarden Y, Kuang WS, Yang-Feng T, Coussens L, Munemitsu S, Dull TJ, et al. Human proto-oncogene, c-kit, a new cell surface receptor tyrosine kinase for an unidentified ligand. EMBO J 1987;6:3341-51.

12. Matsuda R, Takahashi T, Nakamura S, Sekido Y, Nishida K, Seto M, et al. Expression of the c-kit protein in human solid tumors and in corresponding fetal and adult normal tissues. Am J Pathol 1993;142:339-46.

13. Lux ML, Rubin BP, Biase TL, Chen CJ, Maclure T, Demetri G, et al. KIT extracellular and kinase domain mutations in gastrointestinal stromal tumors. Am J Pathol 2000;156:791-5.

14. Ricotti E, Fagioli F, Garelli E, Linari C, Crescenzio N, Norenstein AL, et al. c-kit is expressed in soft tissue sarcoma of neuroectodermic origin and its ligand prevents apoptosis of neoplastic cells. Blood 1998;91:2397-405.

15. Wang WL, Healy ME, Sattler M, Verma S, Lin J, Maulik G, et al. Growth inhibition and modulation of kinase pathways of small cell lung cancer cell lines by the novel tyrosin kinase inhibitor STI 571. Oncology 2000;19:3521-8.

16. Joensuu H, Roberts PJ, Sarlomo-Rikala M, Anderson LC, Tervahartiala $\mathrm{P}$, Tuveson $\mathrm{D}$, et al. Effect of the tyrosine kinase inhibitor STI571 in a patient with a metastatic gastrointestinal stromal tumor. N Engl J Med 2001;344:1052-6.

17. Cobleigh MA, Vogel CL, Tripathy D, et al. Multinational study of the efficacy and safety of humanized anti-Her2 monoclonal antibody in women who have Her2overexpressing metastatic breast cancer that has progressed after chemotherapy for metastatic disease. J Clin Oncol 1999; 17:2639-48.

18. Barnoud R, Sabourin JC, Pasquier D, Ranchere D, Bailly C, Terrier-Lacombe MJ, et al. Immunohistochemical expression of WT1 by desmoplastic small round cell tumor: a comparative study with other small round cell tumors. Am J Surg Pathol 2000;24:830-6.

19. Barr FG, Chatten J, D'Cruz CM, Wilson AE, Nauta LE, Nycum LM, et al. Molecular assays for chromosomal translocations in the diagnosis of pediatric soft tissue sarcomas. JAMA 1995;273:553-7.

20. Charles AK, Moore IE, Berry PJ. Immunohistochemical detection of the Wilm's tumour gene WT1 in desmoplastic small round cell tumour. Histopathology 1997;30:312-4.

21. Ordonez NG. Desmoplastic small round cell tumor. II. An ultrastructural and immunohistochemical study with emphasis on new immunohistochemical markers. Am J Surg Pathol 1998;22:1314-27.

22. Goldsmith JD, Pawel B, Goldblum JR, Pasha TL, Robert S, Khurana JS, et al. Detection and diagnostic utilization of placental alkaline phosphatase in muscular tissue and tumors with myogenic differentiation. Am J Pathol 2002;26: 1627-33.

23. Armstrong JF, Pritchard-Jones K, Bickmore WA, Hastie HD, Bard JB. The expression of the Wilms' tumour gene, WT1, in the developing mammalian embryo. Mech Dev 1993;40:8597.

24. Little M, Wells C. A clinical overview of WT1 gene mutations. Hum Mutat 1997;9:209-25.

25. Parkash V, Gerald WL, Parma A, Miettinen M, Rosai J. Desmoplastic small round cell tumor of the pleura. Am J Surg Pathol 1995;19:659-65.

26. Choi JK, van Hoeven K, Brooks JJ, Gupta PK. Desmoplastic small round cell tumor presenting pleural fluid and accompanied by desmin-positive mesothelial cells. Acta Cytol 1995;39:377-8.

27. Wolf AN, Ladanyi M, Paull G, Blaugrund JE, Westra WH. The expanding clinical spectrum of desmoplastic small roundcell tumor: a report of two cases with molecular confirmation. Hum Pathol 1999;30:430-5. 
28. Doglioni C, Tos AP, Laurino L, Iuzzolino P, Chiarelli C, Celio MR, et al. Calretinin: a novel immunocytochemical marker for mesothelioma. Am J Surg Pathol 1996;20:1037-46.

29. Rogers JH. Calretinin: a gene for a novel calcium-binding protein expressed principally in neurons. J Cell Biol 1987; 105:1343-53.

30. Trupiano JK, Machen SK, Barr FG, Goldblum JR. Cytokeratin-negative desmoplastic small round cell tumor: a report of two cases emphasizing the utility of reverse transcriptase-polymerase chain reaction. Mod Pathol 1999; 12:849-53.

31. Ordonez NG, Desmoplastic small round cell tumor. I. A histopathologic study of 39 cases with emphasis on unusual histological patterns. Am J Surg Pathol 1998;22:1303-13.

32. Smithey BE, Pappo AS, Hill DA. C-kit expression in pediatric solid tumors. Am J Surg Pathol 2002;26:486-92.

\section{Book Review}

Weldon D: Skin Pathology, Second Edition, 1172 pp, London, Churchill Livingstone, 2002 (\$299.00).

Winston Churchill once wrote that "a syndicate can comprise an encyclopaedia, only a man can write a book." This awe-inspiring book proves that Sir Winston was right about the notable single author books, but it also shows the reverse, i.e., that you do not need always a syndicate to comprise an encyclopedia. At least not an encyclopedia of dermatopathology.

I became aware of the first edition of Dr. Weldon's book after a former resident of mine returned from his East Coast dermatopathology fellowship and magisterially declared that this will be the book from which he will teach the dermatology and pathology trainees. The enthusiasm of that young man made me buy the book, and not long thereafter it became my favorite source of fancy names for common and not so common skin lesions. I also realized that this is indeed a most comprehensive, yet understandable, text with a lot of wisdom on its pages. I concluded that it must have been written by a master diagnostician who can translate his thoughts into clear declarative sentences and is at the same time devoted to teaching basics as well as the intricacies of dermatopathology. No wonder that the first edition was so widely praised and recognized by the Medical Book Award for 1998 from the Medical Society of London.

Like the first edition, the second one is heavy; it weighs over $3 \mathrm{~kg}$ on my dissection room scale. It contains 200 more pages than the first edition and is more profusely illustrated. The text was updated whenever necessary and the new references inserted. It is undoubtedly as good and in some aspects even better than the first edition. It is not inexpensive, but if you can afford only one dermatopathology book for you library this should be it. Residents in pathology and dermatology should be advised to read it systematically and thoughtfully and keep it handy next to the microscope while studying skin biopsies.

\section{Ivan Damjanov University of Kansas School of Medicine Kansas City, Kansas}

